\title{
Technological Progress in US Agriculture: Implications for Biofuel Production
}

\author{
Farzad Taheripour ${ }^{1}$, Don Scott $^{2}$, Cristopher A. Hurt ${ }^{1} \&$ Wallace E. Tyner ${ }^{1}$ \\ ${ }^{1}$ Department of Agricultural Economics, Purdue University, West Lafayette, IN, USA \\ ${ }^{2}$ Rock House Advisors, USA \\ Correspondence: Farzad Taheripour, Deaprtment of Agricultural Economics, Purdue University, 403 West State \\ S., West Lafayette, IN, USA. Tel: 765-838-2289. E-mail: tfarzad@ purdue.edu
}

Received: October 21, 2020 Accepted: December 12, 2020 Online Published: January 6, 2021

doi:10.5539/sar.v10n1p61

URL: https://doi.org/10.5539/sar.v10n1p61

\begin{abstract}
This paper evaluates in a holistic way major trends in US production of food, feed, and biofuel commodities over the period 1961-2014. It is motivated by literature that examines parts of the changes but does not integrate them. We develop a comprehensive data set and then conduct analysis of the major trends that emerge. We identify eight major trends and then combine them to four major themes. The first theme is the huge gain in agricultural productivity over this period. An important component of this theme is that the productivity gain was sufficient to achieve substantial total production growth as agricultural land declined over the period. Second, there has been a major transformation of the livestock sector as less efficient and more expensive beef has been replaced by more efficient and less expensive poultry. As this change has happened, the livestock sector has become more land efficient, less land used in livestock. The third major change is that US calorie production is now substantially more than the needs for food and feed. Finally, the first three major themes have enabled the fourth, which is growth of US renewable fuel production, while agricultural land declined over time.
\end{abstract}

Keywords: technological progress, US agriculture, livestock, biofuels, food, and feed

\section{Introduction}

In recent years, two major distinct groups of papers have addressed the land use implications of agricultural activities. The first group has expressed concerns on induced land use changes due to biofuel production, and the second group highlighted the implications of expansion in demand for animal-based food products. This paper analyzes the performance of US agriculture with respect to these two sources of demand stimulation and examines their induced land us changes using historical data for the time period of 1961-2014.

A large number of papers have estimated induced land use changes for biofuel produced in the US. Some of these papers estimated that biofuel production from agricultural resources leads to a huge expansion in crop production and higher demand for cropland and that leads to major deforestation across the world (a few examples are: Tilman et al., 2006; Fargione et al., 2008; Searchinger et al., 2008). These papers suffer from several deficiencies and limitations. They usually ignore the role of market mediated responses and neglect the contribution of technological progress in crop production. In addition, they assumed that there is no idled land and no multiple cropping across the world. On the other hand, in this research category, several papers that removed these deficiencies and limitation from their estimation process projected significantly smaller induced land use changes for biofuel production (a few examples are: Hertel et al. 2010; Laborde, 2011; Taheripour and Tyner, 2013; Taheripour et al., 2017). While the results of the second group of papers are more consistent with real observations, to the best of our knowledge, no effort has been made to evaluate the extent to which biofuel production has contributed to the observed land use changes in the US.

In a different but related research area, many papers have expressed concerns about the rapid expansion in demand for animal-based food products (a few examples are: Godfray et al., 2010; Foley et al., 2011; Cassidy et al., 2013; Pradhan et al., 2013; West et al., 2014; Peters et al., 2016). The sole argument in these papers is that the efficiency of converting feed items to the animal-based food products is extremely low. Hence huge amounts of feed crops or large areas of pastureland are needed to satisfy the exiting demand for these food items. As an example, Shepon et al. (2016) have estimated that the overall caloric and protein efficiency rates for the 
animal-based food items (including beef, poultry, pork, egg, and dairy) produced in US are about $7 \%$ and $8 \%$, respectively. These papers usually call for modification in dietary patterns and seek alternatives to move away from animal-based food items. As an example, Cassidy et al. (2013) calculated that it is possible to provide food for an additional 4 billion people across the world with changes in the current mix of crops and growing crops for direct human consumption. While these papers address several important points and highlight hypothetical alternatives, no major analysis has been made to determine the extent to which the expansion in demand for animal-based food products affected land use changes in the US. This paper aims to accomplish this task.

In this paper, following Cassidy et al. (2103), we first develop a comprehensive accounting framework to measure total supply of calories produced by the US crop sector over the time period of 1961-2014. In this calculation, we extend the framework used by Cassidy et al. (2013) to include production of animal feed crops such as alfalfa, silages, and other cultivated feed grasses. We then determine the shares of food, feed, net exports, and biofuels in total supply of US calories. Next, we examine the changes in land cover items and harvested areas in response to the changes in crop and livestock output over the time period 1961-2014. This helps us to develop productivity measures for the US crop and livestock sectors. Our results show that over the examined period of 1961-2014:

1) Productivity of the crop sector has increased by $1.54 \%$ per year,

2) The joint share of corn and soybeans in total crop calories produced in the US has increased over time from $38 \%$ in 1961 to $70 \%$ to 2014. Productivity of livestock - measured with different indices - has also increased largely,

3) Area of available cropland and pastureland decreased over time,

4) The share of net export in calories produced increased to about $30 \%$ in 1980 and then dropped to about $20 \%$ in 1990 and remained relatively flat thereafter,

5) The share of livestock in crop calories produced dropped from $74 \%$ in 1961 to $50 \%$ in 2014,

6) The supply of crop calories for food uses (including waste and exports of processed food items) has increased over time from $156.3 \mathrm{Pcal}\left(10^{\wedge} 12 \mathrm{Kcal}\right)$ to $441.8 \mathrm{Pcal}$ in 2014 ,

7) The ratio of crop calories used for food over the required crop calories to meet the demand for crop calories has increased over time from 2 in 1961 to 3.3 in 2014,

8) Finally, the share of crop calories used for biofuels has increased over time from zero to $5 \%$ in 2005 and then increased to about 16\% in 2014 and dropped to $14 \%$ in 2014.

\section{Method and Data}

Traditionally, data on production and consumption of agricultural products were published and used in mass units (and sometimes in monetary values). These units of measurement do not reflect the nutritional values of agricultural products. In addition, in dealing with aggregate data on food products, it is relatively meaningless to use mass units. Recently, several attempts have been made (a few examples are: Foley et al., 2011; Cassidy et al., 2013; Pradhan et al., 2013) to evaluate production and consumption of these products using a calorie unit to provide more accurate information on production/consumption of agricultural products and directly show their link to human dietary needs. In this paper, we build on the approach developed by Cassidy et al. (2013) to provide an overall accounting framework to determine production of crop calories and their consumption in alternative uses including net exports, feed, food, and biofuel. We do not examine make up of these calories within the primary macronutrient categories of protein, carbohydrates, and fat. The work presented here on total calories may be improved by disaggregating these macronutrient categories. The food category represents: Production - (Net exports + Feed). Hence, it basically captures crop calories used as food and also waste. This category does not capture crop calories consumed indirectly through consumption of animal products. Finally, we do not count imported and exported processed foods.

The framework developed by Cassidy et al. (2013) encompasses 41 crops that cover approximately $90 \%$ of crop calories used across the word in 2000 , according to these authors. This framework misses many crops including several important feed crops including all types of silages, fodders, forages, and cultivated grasses for animal feed crops. Examples are: corn for silage, sorghum for silage, rye for silage, alfalfa, and so on. The missing crops have a large share in total calories produced in the US. To remove this restriction, we included all type of crops produced in the US including all feed crops. Our framework includes 92 types of crops. The list of crops is included in Appendix.

The framework developed by Cassidy et al. (2013) only represents crops produced in 2000. We extend our framework to cover the time period of 1961 to 2014. Unlike the earlier work in this area, we extend our 
framework to examine changes in allocation of crop calories across their alternative uses over time. In addition to crop calories we included animal-based food products including ruminant meat, pork, poultry, dairy products, and eggs.

In recent years, some papers argued that the nutritional content of crops per mass may change over time due to climate change (for example see: Medek et al. 2017). Due to the existing uncertainties in this area of research and unavailability of reliable data for all crop types, we assume that the nutritional content of each crop per metric ton has not changed over time. To convert animal-based products to calories we relied on the conversion coefficients provided by Shepon et al. (2016) and Pradhan et al. (2013).

The required data on crop production, harvested area and livestock output are obtained from the FAO data set. This data set was traditionally providing information for all types of feed crops including silages, fodders, forages, and cultivated grasses for animal feed crops. In recent years, these crops were eliminated from the FAO data set. However, we were able to retrieve the information on production and harvested area of these crops from an old backup of this data set from 1961 to 2012. We matched this information with a similar data set provided by the USDA, known as Feed-Grain data set. We find that the old FAO data set and the USDA Feed-Grain data set provide similar information for the US with some minor differences. Hence, for the missing feed crops from the FAO data set, we used the USDA Feed-Grain data set for the entire period of 1961-2014.

The livestock industry also uses a large portion of several grains such as corn, sorghum, oats, barley, and many more as feed. We used the USDA data sets to determine the share of feed in each of these crops. We also relied on the USDA data sets for the trade of agricultural products from the US and to the US. To estimate demand for calories, we used the US censuses to determine the US population by age groups and gender for the period of 1961-2014.

Finally, for the area of cropland and pastureland we used the US Agricultural Censuses data, as the FAO uses this information as well. The areas of "arable land and permanent crops" in the FAO data set are similar to the areas of "cropland" provided by the US Agricultural Census for the conducted census years. Also, the areas of "permanent meadows and pasture" in the FAO data set are similar to the area of "pastureland" provided by the US Agricultural Census for the conducted census years. The US Agricultural Censuses label a portion of US cropland as "crop land in pasture", known as "cropland pasture". We subtracted the areas of "cropland pasture" from the areas of "cropland" and added to that to the area of "pastureland", as this portion of cropland is used as pastureland.

\section{Results}

\subsection{Production}

In general, total production of crops, measured in calories has increased rapidly over time from 1045.3 Pcal $\left(10^{\wedge} 12 \mathrm{kcal}\right)$ in 1961 to $2418.6 \mathrm{Pcal}$ in 2014 . This means that production of US crop calories has increased by an annual growth rate of $1.6 \%$ over the period of $1961-2014$. The US population growth rate was slightly less than 1 percent per year in this time period. Note that the observed major fluctuations in crop calories basically represent the impacts of changes in weather.

During the same time period production of animal-based products (including ruminant meat, poultry, pork, milk, and eggs) measured in calories has increased from 87 Pcal in 1961 to 179.3 Pcal. Therefore, production of US animal-based calories has increased by an annual growth rate of $1.4 \%$ over the examined time period, again larger than population growth, but smaller than the growth in crop calories. Figure 1 shows changes in crop and livestock products over time. 


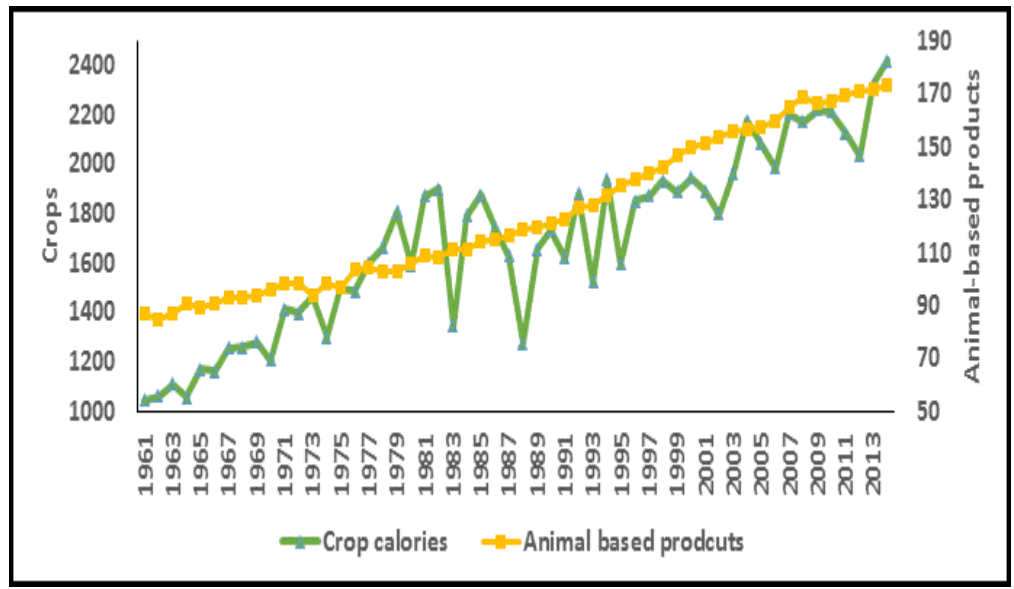

Figure 1. US production of crops and animal-based food products measured in calories (in Pcal)

\subsection{Uses of Crop Calories}

We allocated crop calories produced in the US into four categories of net exports, feed, food, and biofuel. Table 1 represents calories used in each of these categories and their shares in total calories for the time period of 1961 to 2014. This table shows that feed has always the largest share. However, the share of this category dropped from $74 \%$ in 1961 to 58\% in 1990 and then to $49 \%$ in 2014. The annual growth rate for this category is about $0.8 \%$ for the time period of 1961 to 2014, lowest among all categories.

Table 1. Consumption of crop calories produced in the US (in Pcal)

\begin{tabular}{|c|c|c|c|c|c|c|c|c|c|c|}
\hline \multirow[t]{2}{*}{ Year } & \multicolumn{5}{|c|}{ Calories in Pcal } & \multicolumn{5}{|l|}{ Shares in $\%$} \\
\hline & Net export & Feed & Food & Biofuel & Total & Net export & Feed & Food & Biofuel & Total \\
\hline 1961 & 116.0 & 773.1 & 156.3 & 0.0 & 1045.4 & 11.1 & 74.0 & 14.9 & 0.0 & 100.0 \\
\hline 1970 & 173.4 & 875.5 & 159.7 & 0.0 & 1208.5 & 14.3 & 72.4 & 13.2 & 0.0 & 100.0 \\
\hline 1980 & 460.6 & 902.6 & 228.9 & 0.0 & 1592.1 & 28.9 & 56.7 & 14.4 & 0.0 & 100.0 \\
\hline 1990 & 325.4 & 1011.6 & 381.9 & 16.7 & 1735.5 & 18.7 & 58.3 & 22.0 & 1.0 & 100.0 \\
\hline 2000 & 376.7 & 1107.0 & 424.6 & 36.1 & 1944.4 & 19.4 & 56.9 & 21.8 & 1.9 & 100.0 \\
\hline 2005 & 381.7 & 1166.7 & 444.4 & 89.4 & 2082.2 & 18.3 & 56.0 & 21.3 & 4.3 & 100.0 \\
\hline 2006 & 379.3 & 1097.0 & 395.0 & 115.5 & 1986.8 & 19.1 & 55.2 & 19.9 & 5.8 & 100.0 \\
\hline 2007 & 453.7 & 1148.5 & 444.6 & 158.5 & 2205.3 & 20.6 & 52.1 & 20.2 & 7.2 & 100.0 \\
\hline 2008 & 373.7 & 1130.0 & 443.4 & 225.3 & 2172.4 & 17.2 & 52.0 & 20.4 & 10.4 & 100.0 \\
\hline 2009 & 400.9 & 1091.7 & 472.0 & 257.5 & 2222.0 & 18.0 & 49.1 & 21.2 & 11.6 & 100.0 \\
\hline 2010 & 426.5 & 1099.7 & 384.3 & 302.3 & 2212.9 & 19.3 & 49.7 & 17.4 & 13.7 & 100.0 \\
\hline 2011 & 351.7 & 1081.0 & 362.3 & 335.0 & 2129.9 & 16.5 & 50.8 & 17.0 & 15.7 & 100.0 \\
\hline 2012 & 258.0 & 1075.2 & 381.2 & 319.4 & 2033.8 & 12.7 & 52.9 & 18.7 & 15.7 & 100.0 \\
\hline 2013 & 425.2 & 1154.4 & 409.8 & 332.5 & 2322.0 & 18.3 & 49.7 & 17.6 & 14.3 & 100.0 \\
\hline 2014 & 430.4 & 1192.2 & 441.8 & 354.3 & 2418.6 & 17.8 & 49.3 & 18.3 & 14.6 & 100.0 \\
\hline Annual growth\% & 2.5 & 0.8 & 2.0 & NA & 1.6 & NA & NA & NA & NA & NA \\
\hline
\end{tabular}

The share of net exports has increased from $11 \%$ in 1961 to about $20 \%$ in 2000 and then fluctuated around $18 \%$. In 2011 and 2012 the share of net exports dropped to $16.5 \%$ and $12.7 \%$ due to drought and also expansion in biofuels. In general net exports has increased from 116 Pcal in 1961 to 430.4 Pcal in 2014 at an annual growth rate of $2.5 \%$. The amounts of crop calories delivered to food, regardless of the carbohydrate, protein, and oil content, has increased from $156.3 \mathrm{Pcal}$ in 1961 to $441 \mathrm{Pcal}$ in 2014 at an annual rate of $2 \%$ - twice of the population growth rate. The amounts of per capita per day crop calories delivered to food, again regardless of the carbohydrate, protein, and oil content, have significantly increased over time from 2257 calories in 1961 to 3810 calories in 2014. It is important to note that crop calories delivered for food were not used entirely by the US population, as a portion of that was used for seed, and a portion was exported to other counties as exports of processed foods. Also, one should take into account crop waste, as food waste is not negligible in US (Hall et al., 2009). 


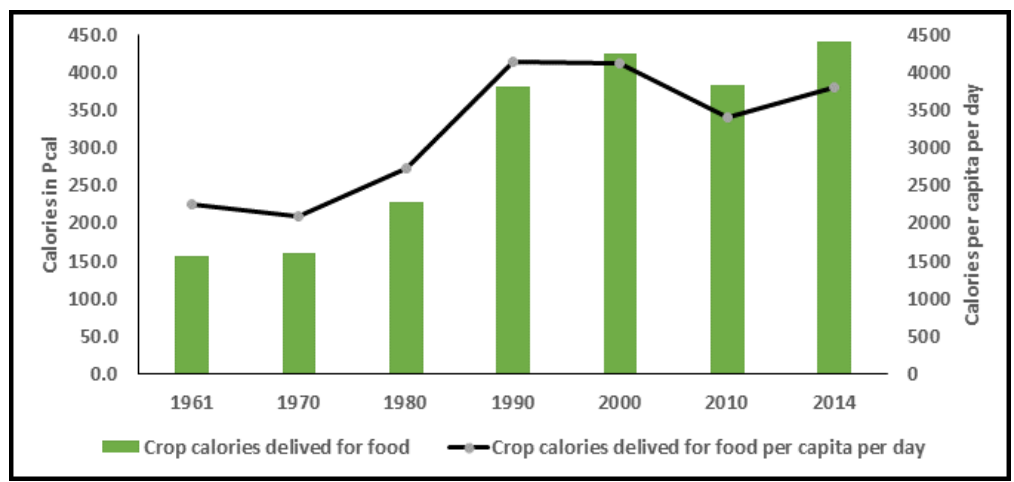

Figure 2. Crop calories delivered for food

The last category of uses reflects crop calories used for production of biofuels, net of feed by-products such as DDGS and meals. This category has zero, or a negligible share until 1980. Then the share of this category grows to $1 \%$ in $1990,1.9 \%$ in 2010 , and $4.3 \%$ in 2005 . Then this share rapidly grows to $14.3 \%$ in 2014 . Table 1 indicates that the reduction in the share of the livestock industry in crop calories provided room for the expansion in the share of biofuels in crop calories in the long run. However, when production of crop calories dropped due to weather conditions (drought years 2010-13 peaked in 2012) the shares of food and exports dropped slightly to maintain the share of biofuels. Later in this paper we show that efficiency improvement in the livestock industry helped enable US biofuel production.

\subsection{Evolution in the Mix of Crops and Animal-based Products}

Over the period of 1961 to 2014 the mix of crops produced within US has changed significantly. To analyze the observed changes in this mix, first we examine changes in harvested area and its mix. Table 2 shows US harvested areas in two broad crop categories.

Table 2. Harvested area of US (million hectares)

\begin{tabular}{llll}
\hline Year & Group $1 *$ & Group 2** & Total \\
\hline 1961 & 89.2 & 31.0 & 120.2 \\
1970 & 88.0 & 29.2 & 117.2 \\
1980 & 112.1 & 28.6 & 140.7 \\
1990 & 100.7 & 20.1 & 120.8 \\
2000 & 101.4 & 19.8 & 121.2 \\
2005 & 99.4 & 21.3 & 120.7 \\
2006 & 95.8 & 21.4 & 117.2 \\
2007 & 99.6 & 21.3 & 121.0 \\
2008 & 101.8 & 18.5 & 120.3 \\
2009 & 99.2 & 18.0 & 117.2 \\
2010 & 100.6 & 21.0 & 121.6 \\
2011 & 97.2 & 20.8 & 118.0 \\
2012 & 102.8 & 20.8 & 123.5 \\
2013 & 100.5 & 20.8 & 121.3 \\
2014 & 102.7 & 20.8 & 123.5 \\
Annual growth in \% & 0.3 & -0.8 & 0.1 \\
\hline
\end{tabular}

* Group 1: includes all food crops (e.g. fruits, vegetables, nuts) and crops that could and have been used as food, animal feed, or feedstock for biofuels (e.g. corn, soybean, barely).

** Group 2: includes all feed crops such as silages and cultivated grasses.

Group 1: includes all food crops (e.g. fruits, vegetables, nuts) and crops that could and have been used as food, animal feed, or feedstock for biofuels (e.g. corn, soybean, barely). Group 2: includes all feed crops such as silages and cultivated grasses. Table 1 shows that total harvested area of US has increased from 120 million hectares (MH) in 1961 to $140 \mathrm{MH}$ in 1980 and then fall to $120 \mathrm{MH}$ in 1990 and remained around this figure thereafter until 2009 and then slightly increased to $123 \mathrm{MH}$ in 2014. Hence, regardless of the abnormal condition 
in 1980s, harvested area of US remained around $120 \mathrm{MH}$ during the rest of the examined time period of 1961 to 2014. The harvested area of Group 1 has increased from 89 MH in 1961 to $103 \mathrm{MH}$ in 2014 while the harvested area of the second grouped dropped from $31 \mathrm{MH}$ to $21 \mathrm{MH}$ in the same time period. This indicates that the observed expansion in harvested area of the first group of crops comes from the reduction in animal feed crops of silages and cultivated grasses.

Consider now Figure 3 which shows another categorization of crops produced in US. This figure divides crops into four groups: Food-Feed crops including all crops that can be used as feed or food except corn and soybeans; Cultivated grasses and silages; Corn-Soybeans; and Food crops. This figure shows that over time the shares of food-feed and cultivated grasses and silages in total harvested area has dropped sharply while the joint share of corn-soybeans has increased sharply from $28.5 \%$ in 1961 to $54.3 \%$ in 2014 . The share of food crops increased slightly from $6.2 \%$ to $7.3 \%$ in $1961-2018$.

Figure 3 clearly indicates that over time the US crop industry has switched to corn and soybeans (two high calorie content crops) instead of producing other types of low efficiency crops that had been used by the livestock industry. Perhaps, this shift has been aided by the huge technological progress in production of corn and soybeans. These crops, which produced significant quantities of protein, carbohydrates, and fat provided the greatest potential for return on investment. Investment in research and commercialization has resulted in continued yield gains.

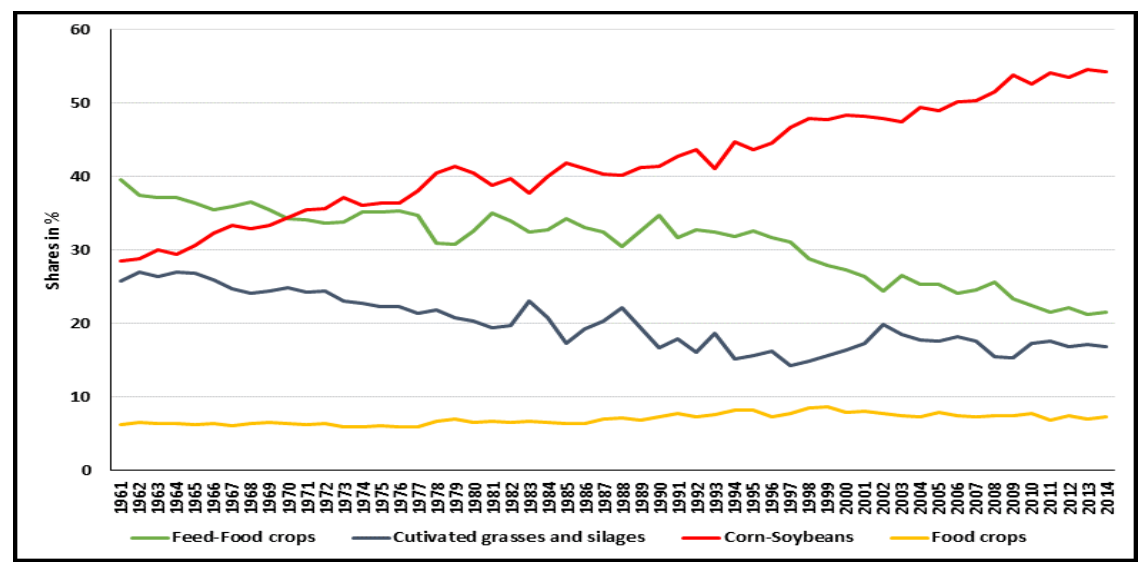

Figure 3. Shares of crop categories in total harvested area of US

Due to this switch, the joint share of corn and soybeans in total crop calories produced in US has continuously increased over time from 38\% in 1961 to $70 \%$ in 2014, as indicated in Figure 4. The implications of this shift for food, feed, and biofuels will be discussed in the rest of this paper.

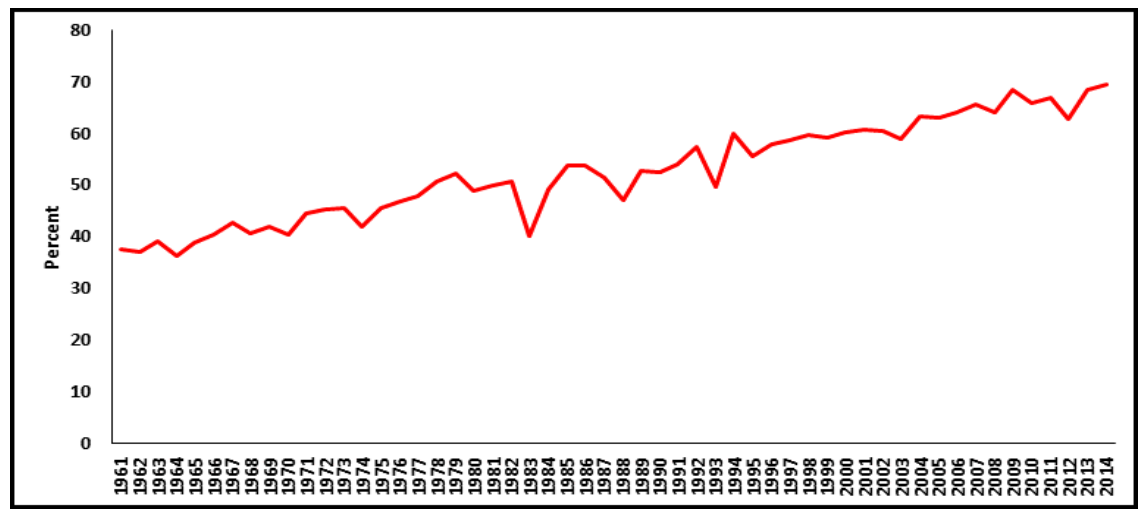

Figure 4. Joint share of corn and soybean in crop calories produced in US

Over the period of 1961 to 2014 the mix of animal-based food products has also changed significantly, as shown in Table 3. This table shows that while all types of animal-based products have increased over time, the size and 
share of poultry products have increased significantly faster than other products. In 1961 production of poultry was about 8.1 Pcal. The production of poultry products has increased at an annual growth rate of $3.4 \%$ over time and reached to $47.5 \mathrm{Pcal}$ in 2014. Other types of animal-based products had much smaller growth rates, from $0.8 \%$ to $0.9 \%$ per year. Hence, the share of poultry in total animal-based calories produced in US has increased from $9.1 \%$ in 1961 to $27.4 \%$.

On the other hand, the share of beef declined from $28.8 \%$ in 1961 and $34.5 \%$ in 1970 to $21.7 \%$ in 2014 . These figures represent a major change in the mix of livestock outputs from beef with a low caloric feed to food conversion efficiency rate to poultry with a high caloric feed to food conversion efficiency). According to Shepon et al. (2106) the conversion efficiencies for these two types of animal products are about 3\% and 17\%, respectively. The switch from beef to poultry generated a major productivity gain and land intensification for the US livestock industry in general. During the period of 1961-2014 with some exceptions the shares of pork, milk, and eggs fluctuated around $14 \%, 31 \%$ and $5 \%$, respectively.

Table 3. Caloric animal-based food products produced in US (in Pcal)

\begin{tabular}{ccrrrrrrrrrrr}
\hline \multirow{2}{*}{ Year } & \multicolumn{1}{c}{ Calories in Pcal } & \multicolumn{4}{c}{ Shares in \% } \\
\cline { 2 - 13 } & Beef & Poultry & Pork & Milk & Eggs & Total & Beef & Poultry & Pork & Milk & Eggs & Total \\
\hline 1961 & 25.0 & 8.1 & 14.5 & 34.2 & 5.2 & 87.0 & 28.8 & 9.3 & 16.7 & 39.3 & 5.9 & 100.0 \\
1970 & 33.2 & 11.2 & 14.0 & 31.8 & 5.7 & 95.9 & 34.6 & 11.7 & 14.6 & 33.2 & 5.9 & 100.0 \\
1980 & 32.7 & 15.4 & 17.3 & 34.9 & 5.8 & 106.2 & 30.8 & 14.5 & 16.3 & 32.9 & 5.4 & 100.0 \\
1990 & 34.3 & 25.2 & 16.0 & 40.2 & 5.6 & 121.4 & 28.3 & 20.8 & 13.2 & 33.1 & 4.7 & 100.0 \\
2000 & 38.9 & 38.7 & 19.8 & 45.6 & 7.0 & 149.9 & 25.9 & 25.8 & 13.2 & 30.4 & 4.7 & 100.0 \\
2005 & 36.1 & 43.8 & 21.6 & 48.2 & 7.5 & 157.2 & 23.0 & 27.9 & 13.7 & 30.6 & 4.8 & 100.0 \\
2006 & 36.3 & 44.2 & 22.0 & 49.5 & 7.6 & 159.6 & 22.8 & 27.7 & 13.8 & 31.0 & 4.8 & 100.0 \\
2007 & 38.5 & 45.2 & 22.9 & 50.5 & 7.6 & 164.6 & 23.4 & 27.4 & 13.9 & 30.7 & 4.6 & 100.0 \\
2008 & 38.8 & 46.3 & 24.4 & 51.7 & 7.5 & 168.7 & 23.0 & 27.4 & 14.4 & 30.7 & 4.4 & 100.0 \\
2009 & 39.0 & 44.2 & 24.0 & 51.5 & 7.5 & 166.3 & 23.5 & 26.6 & 14.4 & 31.0 & 4.5 & 100.0 \\
2010 & 38.2 & 45.6 & 23.4 & 52.5 & 7.6 & 167.3 & 22.8 & 27.3 & 14.0 & 31.4 & 4.5 & 100.0 \\
2011 & 38.6 & 46.1 & 23.8 & 53.4 & 7.7 & 169.6 & 22.8 & 27.2 & 14.0 & 31.5 & 4.5 & 100.0 \\
2012 & 38.4 & 46.1 & 24.3 & 54.6 & 7.8 & 171.3 & 22.4 & 26.9 & 14.2 & 31.9 & 4.6 & 100.0 \\
2013 & 38.0 & 46.8 & 24.2 & 54.8 & 8.1 & 171.9 & 22.1 & 27.2 & 14.1 & 31.9 & 4.7 & 100.0 \\
2014 & 37.7 & 47.5 & 23.8 & 56.1 & 8.4 & 173.5 & 21.7 & 27.4 & 13.7 & 32.3 & 4.8 & 100.0 \\
Annual growth\% & 0.8 & 3.4 & 0.9 & 0.9 & 0.9 & 1.3 & NA & NA & NA & NA & NA & NA \\
\hline
\end{tabular}

\subsection{Areas of Cropland and Pastureland}

The area of US cropland (excluding cropalnd pasture) flactualted between $147 \mathrm{MH}$ to $153 \mathrm{MH}$ and most of the time remained close to $150 \mathrm{MH}$ aover the period of 1961-2014, as shown in Figure 5. During this time period, area of pasture land dropped from $217 \mathrm{MH}$ to about $170 \mathrm{MH}$ in 2014. The sum of these two types of land dropped by about $47 \mathrm{MH}$ over the examined period of 1961-2014. Hence, while ouptputs of US agricultural sector have increased massively in 1961-2104, this sector has used less net land over time.

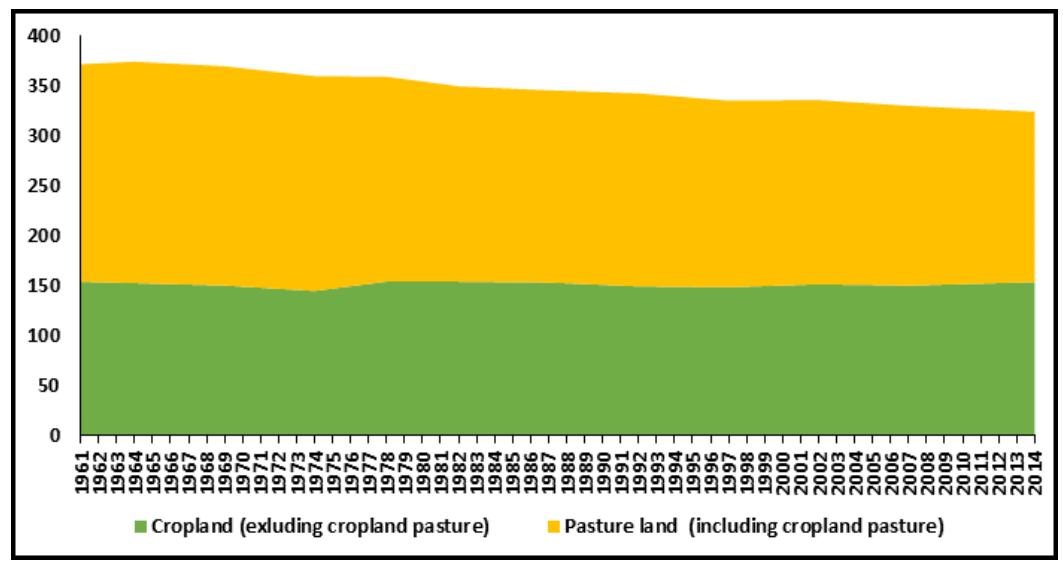

Figure 5. Areas of US cropland and pasture land (in million hectares) 


\subsection{Productivity and Intensification}

Productivity growth has played an important role in the US agriculture during the past century. Nearly 70 years ago, in a seminal review of US agriculture, Salter (1950) who reviewed and summarized improvements in productivity of US agriculture in the first half of the $20^{\text {th }}$ century argued that US agriculture gained magnificent progress in yield improvement in that time period and said that the "big harvest" will happen in the second half of this century. This bright projection came true. The existing literature confirms that productivity growth has been the sole source of economic growth in US agriculture during the second half of the past century and continued thereafter (Kendrick and Grossman (1980); Jorgenson et al. (1987); Jorgenson and Gollop (1992); Jorgenson et al. (2005), Fuglie et al. (2007), and Ball et al. (2016)). Jorgenson et al. (2005) have shown that 80\% of the observed growth in the US agricultural production during the time period of 1977-2000 was due to improvement in productivity. In a comprehensive work Ball et al. (2016) have calculated that US agricultural productivity has increased $1.47 \%$ per year during the period 1948-2013, while areas of pasture and cropland has followed declining trends in this time period. In what follows we develop some indices to represent yield improvement in US agriculture.

First, consider figure 6 which represents two indices: 1) Index of total production of crops (in tonnes) over harvested area (in hectare) and 2) Index of total production of crops (in calories) over harvested area. The base year is $1961=100$ for both indices. As shown in this figure, both indices represent major improvements in productivity. The first index shows about $90 \%$ growth in productivity (from 100\% in 1961 to 190\% in 2014) and the second index shows $125 \%$ growth in productivity (from 100\% in 1961 to $225 \%$ in 2014). The difference represents the impacts of moving towards more efficient crops, basically corn and soybeans. Using the calorie productivity index, we can see that productivity of land in US crop sector has increased over time at an annual growth rate of $1.54 \%$ over the time period of 1961-2014. This is in line with the findings of Ball et al. (2016). However, our productivity measure shows intensification of calories produced over harvested area, while Ball et al. estimated total factor productivity of US agriculture in general.

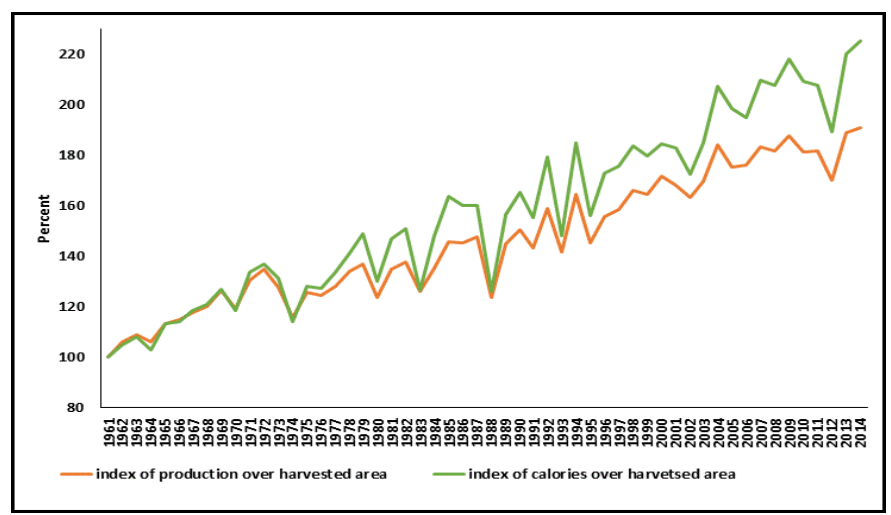

Figure 6. Yield improvement in crop production in US

Livestock sector productivity also has increased during the period of 1961 to 2014 , as shown in table 4 . The first index in this table shows the ratio of production of animal-based calories over crop feed calories. This index has increased from $11.3 \%$ in 1961 to $14.6 \%$ in 2014. This index improved in recent years, after the observed expansion in livestock. Note that this index is larger than the overall efficiency rate for the US livestock industry calculated by Shepon et al. (2016). That is because our ratio only shows feed crops and does not include intake calories from pastureland.

The second index shows production of animal-based calories over area of pastureland (including cropland pasture). This ratio has increased from $399 \mathrm{Pcal} / 1000$ hectares 1961 to $1017 \mathrm{Pcal} / 1000$ hectares in 2104. Again, a large portion of this expansion occurs after 2000 when biofuel production increased rapidly. 
Table 4. Productivity improvement in US livestock industry

\begin{tabular}{lll}
\hline Year & $\begin{array}{l}\text { Production of animal- based calories } \\
\text { over crop feed calories in \% }\end{array}$ & $\begin{array}{l}\text { Production of animal- based calories } \\
\text { over area of pastureland (Pcal/1000 hectares) }\end{array}$ \\
\hline 1961 & 11.3 & 399.4 \\
1970 & 11.0 & 438.7 \\
1980 & 11.8 & 530.1 \\
1990 & 12.0 & 629.1 \\
2000 & 13.5 & 808.9 \\
2010 & 15.2 & 951.0 \\
2014 & 14.6 & 1017.2 \\
\hline
\end{tabular}

\section{Discussion and Conclusion}

The objective of this paper has been to do an empirically based holistic analysis of major trends in US agricultural production and consumption patterns. In the introduction, we identified eight key trends that emerge from the analysis. Here we will summarize those trends and the analysis from the paper into four key themes that summarize the major changes in US food and agriculture.

First, the data clearly show an amazing growth in US agricultural productivity over the period evaluated. This productivity growth is well-known, but the other part of the story is that the gain in production has been accomplished as land allocated to agricultural production has declined. In other words, more calories are now produced from less land. Related to the literature cited here, this means that the doomsday forecasts of declining food availability are not credible.

Second, the data demonstrate a dramatic transformation of the livestock sector both in terms of means of production and consumption patterns. There has been a major shift in meat consumption away from beef to poultry. Poultry is more efficient at converting feed to meat and less expensive for consumers. Beef is much less efficient in feed conversion and more expensive for consumers. There have been health concerns related to red meat as well that may have influenced the shifting consumption pattern. Associated with this shift is a move from using forages to produce meat to much greater use of corn and soybeans. This means that the livestock sector as a whole has become more land efficient, using less land per unit of output. Essentially, nutrient rich corn and soybeans have been substituted for lower productivity and relatively nutrient poor forages. The US agriculture today can produce much more calories and economic value per unit of land. This has partially been driven by changes in the mixes of crops and combination of livestock outputs. Producing more crop feeds allows farmers to produce more protein, carbohydrates, and fat per acre. In addition, producing more crop feeds allows livestock producers greater flexibility in mixing feed rations for optimum weight gain and quality throughout the animal lifecycle at the optimum cost and return on investment. For monogastric species, crop feeds are required, because chickens and turkey cannot eat grass and process cellulose or insoluble carbohydrates as cows can do. For poultry, the switch from forage to soy protein is more than an economical opportunity, it is required to satisfy nutritional requirements and digestive ability. Essentially, what this means is that the productivity gains in producing corn and soybeans have enabled livestock producers to take advantage of these feed inputs thereby requiring less land per unit of ruminant and non-ruminant meat production.

Third, while total US calorie production has grown substantially, the share of crop calories allocated to food also increased. The amount of per capita per day of crop calories delivered to food has increased much faster than the US population growth. A portion of crop calories allocated to food could be exported to other counties and a portion represents food waste, an emerging area in the literature.

The fourth major change is the increase in biofuels production. What should be clear is that this increase in biofuels production has been enabled by the productivity growth and livestock sector transformations described here. In this context, it has not been land that was freed up for biofuels, but calories. A portion of historical farmland has been freed up and is no longer being used to provide crops or pasture. While some of this land could be used for recreation and wildlife habitat, significant amounts have been lost to development. The land which supplies carbohydrates for ethanol or fats for biodiesel also is supplying protein for livestock. Among these required macronutrients, protein is unique in that no protein is used for biofuels. Essentially all protein goes into the food supply. Not only did it become possible to produce far beyond basic food needs and to grow agriculture as a source of renewable energy, but diversifying markets and creating industrial outlets for these excess calories became part of the optimization that increased the affordability and availability of protein needed for the food supply. 
Some of these themes have been explored before in the literature, but they have not been brought together to tell a holistic and coherent story as is done here. Attempts to assess the impact on the farming landscape as a result of biofuels policy without considering the interactions with the livestock sector fail to capture the most significant drivers for changes in the management of agricultural lands. The basic motivation for this analysis was to take a big picture look at what has been happening in US agriculture and explore possible implications. Clearly, the changes in crop productivity and the livestock sector changes need to be considered together to fully understand past changes and foretell future developments.

\section{Acknowledgments}

This research was partially funded by the U.S. Federal Aviation Administration Office of Environment and Energy through ASCENT, the FAA Center of Excellence for Alternative Jet Fuels and the Environment, project 001 through FAA Award Number 13-C-AJFE-PU under the supervision of Anna Oldani. Any opinions, findings, conclusions, or recommendations expressed in this material are those of the authors and do not necessarily reflect the views of the FAA.

\section{References}

Ball, E. V., Wang, S. L., Nehring, R., \& Mosheim, R. (2016). Productivity and Economic Growth in U.S. Agriculture: A New Look, Applied Economic Perspectives and Policy, 38(1), 30-49. https://doi.org/10.1093/aepp/ppv031

Cassidy, E. S., West, P. C., Gerber, J. S., \& Foley, J. A. (2013). Redefining agricultural yields: from tonnes to people nourished per hectare, Environ. Res. Lett., 8, 034015. https://doi.org/10.1088/1748-9326/8/3/034015

Fargione, J., Hill, J., Tilman, D., Polasky, S., \& Hawthorne, P. (2008). Land clearing and the ciofuel carbon debt. Science, 319(5867), 1235-1238. http://doi.org/10.1126/science.1152747

Foley, J. A., Ramankutty, N., Brauman, N. K. A., Cassidy, E. S., Gerber, J. S., Johnston, M., ... Zaks, D. P. M. (2011). Solutions for a cultivated planet. Nature, 478, 337-42. https://doi.org/10.1038/nature10452

Fuglie, K. O., McDonald, J. M., \& Ball, V. E. (2007). Productivity growth in U.S. agriculture. Economic Brief Number 9, Economic Research Service, Washington, D.C.

Godfray, H. C. J., Beddington, J. R., Crute, I. R., Haddad, L., Lawrence, D., .. Toulmin, C. (2010). Food security: The challenge of feeding 9 billion people. Science, 327, 812-8. http://doi.org/10.1126/science.1185383

Hall, K. D., Guo, J., Dore, M., \& Chow, C. C. (2009). Progressive increase of food waste in America and its environmental impact. PLoS ONE, 4(11), e7940.

Hertel, T. W., Golub, A. A., Jones, A. D., O'Hare, M., Plevin, R. J., \& Kammen, D. M. (2010). Effects of U.S. maize ethanol on global land use and greenhouse gas emissions: Estimating market-mediated responses, BioScience, 60(3), 223-231. https://doi.org/10.1525/bio.2010.60.3.8

Jorgenson, D., Gollop, F., \& Fraumeni, B. (1987). Productivity and U.S. Economic Growth. Cambridge, MA: Harvard University Press.

Jorgenson, D., \& Gollop, F. (1992). Productivity Growth in U.S. Agriculture: A Postwar Perspective. American Journal of Agricultural Economics, 74, 745-50. https://doi.org/10.2307/1242588

Jorgenson, D., Ho, M., \& Stiroh, K. (2005). Productivity: Information Technology and the American Growth Resurgence. Cambridge, MA: The MIT Press.

Kendrick, J. W., \& Grossman, E. S. (1980). Productivity in the United States, Trends and Cycles. Baltimore, MD; The Johns Hopkins University Press.

Laborde, D. (2011). Assessing the land use change consequences of European biofuel policies. Washington, DC: IFPRI.

Medek, D. E., Schwartz, J., \& Myers, S. S. (2017). Estimated effects of future atmospheric CO2 concentrations on protein intake and the Risk of Protein Deficiency by Country and Region. Environmental Health Perspectives, 125(087002). https://doi.org/10.1289/EHP41

Peters, C. J., Picardy, J., Darrouzet-Nardi, A. F., Wilkins, J. L., Griffin, T. S., \& Fick, G. W. (2016). Carrying capacity of US agricultural land: ten diet scenarios, Elem. Sci. Anthr., 4, 000116.

https://doi.org/10.12952/journal.elementa.000116

Pradhan, P., Lüdeke, M. K. B., Reusser, D. E., \& Kropp, J. P. (2013). Embodied crop calories in animal products, 
Environ. Res. Lett., 8, 044044. https://doi.org/10.1088/1748-9326/8/4/044044

Searchinger, T., Heimlich, R., Houghton, R. A., Dong, F., Elobeid, A., Fabiosa, J., Tokgoz, S., Hayes, D., \& Yu, T-H. (2008). Use of U.S. croplands for biofuels increases greenhouse gases through emissions from land use change. Science, 319(5867), 1238-1240. https://doi.org/10.1126/science.1151861

Shepon, A., Eshel, G., Noor, E., \& Milo, R. (2016). Energy and protein feed-to-food conversion efficiencies in the US and potential food security gains from dietary changes, Environ. Res. Lett, 11, 105002. https://doi.org/10.1088/1748-9326/11/10/105002

Taheripour, F., \& Tyner, W. E. (2013). Biofuels and land use change: Applying recent evidence to model estimates. Applied Sciences, 3, 14-38. https://doi.org/10.3390/app3010014

Taheripour, F., Cui, H., \& Tyner, W. E. (2017). An exploration of agricultural land use change at the intensive and extensive margins: Implications for biofuels induced land use change. In Z. Qin, U. Mishra \& A. Hastings (Eds.), Bioenergy and Land Use Change. Washington, D.C, American Geophysical Union.

Tilman, D., Hill, J., \& Lehman, C. (2006). Carbon-negative biofuels from low-input high-diversity grassland biomass. Science, 314, 1598-1600. https://doi.org/10.1126/science.1133306

West, P. C., Gerber, J. S., Engstrom, P. M., Mueller, N. D., Brauman, K. A., ... Siebert, S. (2014). Leverage points for improving global food security and the environment. Science, 345(6194), 325-328. https://doi.org/10.1126/science.1246067

\section{Appendix}

List of crop categories including all feed and food items

\begin{tabular}{|c|c|c|}
\hline Crop Categories & Crop Categories & Crop Categories \\
\hline Almonds, with shell & Garlic & Pumpkins, squash and gourds \\
\hline Apples & Ginger & Rapeseed \\
\hline Apricots & Grapefruit (inc. pomelos) & Raspberries \\
\hline Artichokes & Grapes & Rice, paddy \\
\hline Asparagus & Groundnuts, with shell & Rye \\
\hline Avocados & Hazelnuts, with shell & Safflower seed \\
\hline Bananas & Hops & Seed cotton \\
\hline Barley & Kiwi fruit & Sesame seed \\
\hline Beans, dry & Lemons and limes & Sorghum \\
\hline Beans, green & Lentils & Soybeans \\
\hline Berries nes & Lettuce and chicory & Spinach \\
\hline Blueberries & Linseed & Strawberries \\
\hline Buckwheat & Maize & String beans \\
\hline Cabbages and other brassicas & Maize, green & Sugar beet \\
\hline Carrots and turnips & Mangoes, mangosteens, guavas & Sugar cane \\
\hline Castor oil seed & Melons, other (inc. cantaloupes) & Sunflower seed \\
\hline Cauliflowers and broccoli & Millet & Sweet potatoes \\
\hline Cereals, nes & Mustard seed & Tangerines, mandarins, clementines, satsumas \\
\hline Cherries & Nuts, nes & Taro (cocoyam) \\
\hline Cherries, sour & Oats & Tobacco, unmanufactured \\
\hline Chickpeas & Okra & Tomatoes \\
\hline Chillies and peppers, dry & Olives & Vegetables, fresh nes \\
\hline Chillies and peppers, green & Onions, dry & Vegetables, leguminous nes \\
\hline Coffee, green & Oranges & Walnuts, with shell \\
\hline Cow peas, dry & Papayas & Watermelons \\
\hline Cranberries & Peaches and nectarines & Wheat \\
\hline Cucumbers and gherkins & Pears & Forage and silage, Alfalfa, \\
\hline Currants & Peas, dry & Forage and silage, grasses NES, \\
\hline Dates & Peas, green & Forage and silage, green oilseeds, \\
\hline Eggplants (aubergines) & Pineapples & Forage and silage, maize, \\
\hline Figs & Pistachios & Forage and silage, sorghum, \\
\hline Fruit, citrus nes & Plums and sloes & \\
\hline Fruit, fresh nes & Potatoes & \\
\hline
\end{tabular}




\section{Copyrights}

Copyright for this article is retained by the author(s), with first publication rights granted to the journal.

This is an open-access article distributed under the terms and conditions of the Creative Commons Attribution license (http://creativecommons.org/licenses/by/3.0/). 